\title{
THE UNRELIABLE NARRATOR AS A PRECEDENT TO THE POST-TRUTH ERA: SUBJECTIVE PERSONAL MEMOR Y IN THE LITERAR Y AUTOBIOGRAPHIES OF EUDORA WELTY AND TOM ROBBINS ${ }^{1}$
}

\begin{abstract}
Keywords: memory; imagination; confluence; unreliability; autobiography; un-truth Abstract: Trying to find the roots of the current post-truth era, one possible path of origin presents itself when it comes to the literary tradition: the unreliable narrator. How does this phenomenon project itself in such a particular place between fact and fiction, occupied solely by literary autobiographies? Eudora Welty and Tom Robbins, two prominent $20^{\text {th }}$ century literary personas, provide a detailed account of their journey towards self-realization in two connected, yet very different ways. Their memoir and autobiography provides a detailed map of this journey. We can hence speak of positive trauma when it comes to recollection of successful literary careers. Imagination, memory and choice all play an important part in this unique narratives' creative process. Understanding the relationships between these elements provides even more understanding when it comes to unreliability and our own perception of reality. What are the specific details of memory the authors put down on paper in order to make sense of their creative lives? How do we spot their importance? What role does memory play in the creative process of these authors? How do they approach imagination? What is their relationship with their own narrators and protagonists, a.k.a. themselves? Can we trust it? Dare we trust it? And if so, how do we do it as readers? All these questions are to be addressed and discussed in the following article.
\end{abstract}

Since the beginning of the new millennium, autobiography has gone under the umbrella term "life writing" (Schmidt 47) in order to encompass a variety of genres and works that fall under this broad category. This particular research, however, focuses solely on two life narratives written by literary authors about themselves, hence Lejeune's basic definition is sufficient. He defines the autobiography as a "[retrospective retelling in prose that a real person makes about their own existence when they highlight their individual life, especially focusing on the history of their personality]" (Lejeune 14). He uses the term "referential pact" to describe the identity and unity of the author $=$ narrator $=$ main character.

Both Eudora Welty and Tom Robbins have written about their lives with the goal of making sense of their creative journey towards writerhood. They represent crucial voices of the $20^{\text {th }}$ century literary canon that, in their fiction as well as

\footnotetext{
* Palacký University, Olomouc; Czech republic.

${ }^{1}$ This study has been supported by Grant of the Czech Ministry of Education, Youth and Sports No. IGA FF 2018012 (Internationalization of Anglo-American Literary Science, English Linguistics and Translation Studies).
} 
autobiographies, manifest commentaries on all critical levels towards imaginary and real worlds: social, historical, psychological, poetic, political, personal, economical, etc. They both use the referential pact in a specific way, which will prove to be key to an understanding of the principles behind the element of the unreliable narrator, within the context of both post-truth, as well as autobiography. The difference between them manifests in degrees of reliability. The referential pacts work for them and makes their stories believable. They both chose to write their autobiography with a focus on their creative life, Welty even more so since her memoir is a series of lectures on creative writing she gave at Harvard University. Her academic approach is thus more reliable, while Robbins' autobiography is closer to his fiction in terms of reliability.

Connected to reliability is the current era of post-truth. For the purposes of this article, according to the OED, post-truth denotes "circumstances in which objective facts are less influential in shaping public opinion than appeals to emotion and personal belief." This dangerous tendency to abandon the appeal to reason and replace it with appeals to the opposite of reason has been particularly intense, ever since it became the word of the year in 2016. Post-truth plays the role of a default background setting for the understanding of the specific mechanisms of unreliability, which this article will discuss.

Another crucial aspect of this intricate interplay is memory. Giacomo Croci defines memory very simply, in terms of two features as: a) practices or activities of many sorts, which b) aim at building in the present a relation to already occurred events, to what we call, in the everyday language, the past. (Croci 16)

This direct definition focuses on what this article aims to highlight: how the development of self-storytelling (since it concerns literary authors) of the $20^{\text {th }}$ century helped create, or better yet, would help us understand why we find ourselves stuck against the irrational background of post-truth in everyday reality.

Who is the main actant of this setting? The unreliable narrator has an extremely crucial position in the deciphering process of autobiography (as well as fiction). In this case, it is not only identical with the persona of the author, but also the implied author and the main character. Wayne Booth's definition claims that narrators "differ markedly depending on how far and in what direction they depart from their author's norms" (Booth 159). In addition, he comments that this phenomenon is evocative of an "author who is sincerely battling to do justice to his materials ...., [a] battle to deal with the truth" (Booth 214). However, for the purposes of this article and to relate it to contemporary reality, with additional context of fiction, truth is no longer sufficient.

Keeping these necessary principles in mind, a significant modification of usage arises from a new possible term: un-truth. "[If we call reality a fiction, we need to invent a new word for fiction]" (Doležel 10). This is applicable since literary autobiographies occupy this special place between fact and fiction. I propose a retrospective diachronic perspective on truth in order to apply it towards the current issue of real-life (un)reliability. Therefore, the term un-truth is necessary. I define it as an element of fiction whose function is to be believable, its meaning rooted in the real world, yet by no means can it be taken as factual information. One of the most basic and generic principles of creating literary works is that authors must find their way around managing believability. Believability only comprises a partial truth- 
condition, because it also contains an element of doubt/faith. In addition, un-truth is not to be confused with lies - these apply strictly to actual reality.

Unreliable narrators exist to give us antecedents that guide us through quests for truth in real life. Building up trust in the narrator/reader relationship is the main motivation force of a work of fiction. In the case of literary autobiographies, the author's creative voice comes in to reflect on their real lives. Literary autobiographies are hence the closest that imaginative worlds come to reality in terms of substance, and the aforementioned trust is dependent on this specific mechanism. Therefore, they are also the only literary-factual topoi that connect an absolutely essential subjective truthfulness of the author with the reader's mind.

The focalization of the relational aspect of memory with imagination is crucial. Dealing with an unreliable narrator is an exercise in selective memory that helps the reader grasp and understand un-truths in order to confront them first hand as lies in reality. It also helps the reader envision the numerous facets of our reality portrayed by different sources, be it literary or any other kind, a very prevalent aspect of the post-truth era. These are patterns which enable one to understand which of the facets to trust and which ones one not to, and how to question them to reach the point of trust. Lejeune makes reference to error, lies and forgetfulness as parts of what makes the narrative authentic, since authenticity is based more on verisimilitude rather than truth. Robbins asserts in his foreword:

Now, despite my contention that the events described herein are 'absolutely true,' I've never in my life kept anything remotely resembling a journal, so they are at least somewhat subject to the effects of mnemonic erosion, and some folks who were involved at the time may recall them a bit differently. (Robbins xvi)

He asks the reader to bear with him, to take his words with a grain of salt. He admits that subjectivity influenced by temporal distance influenced the writing of his point of view. In contrast, diaries - the autobiographies of the instantaneous inner authenticity - function in a different way. Diaries embody the immediate experience put down in words. What they lack in objectivity, they make up for in authenticity. They are clouded by even more subjectivity and emotionality than the situations of our lifetime that we have gained a little distance from, as in autobiographies. Furthermore, time serves as one of the filters of important influence - while looking back, it is possible to evaluate what the true influence of the lived situation was.

In contrast, estimating what the future holds is another necessary part of literary autobiographies, as well as the focal points of existence of their own unreliable narrator. Robbins as well as Welty dedicate their last pages to this reflection. Curiously enough, Welty chooses this section of her memoir to talk about memory to be used as a tool of inspiration (Welty, One Writer's Beginnings 104). Robbins highlights imagination (Robbins 362). Welty also talks about confluence (Welty, One Writer's Beginnings 104). This is a mechanism of merging. Keeping Iser's adaptation of speech acts in mind, let me postulate a daring proposition: the imaginative speech act is formed by merging of memory, as Welty highlights, with imagination, as proposed by Robbins. 
Trauma, Narrative, Responsibility

However, these merging currents of memory and imagination are beyond simple linearity of text. It does not transform into the reality of what is portrayed to us - rather, the picture, in the frame outgrows its origin as the linearity progresses. In addition to confluence, Welty transforms her art of photography (McHaney 19) into The Eye of the Story (Welty, The Eye of the Story title). This eye serves as a frame of reference for the reader. Consequently, based on Welty's concept of frames, the following two schemes for narrative framing are proposed to make this process of confluence more intelligible:

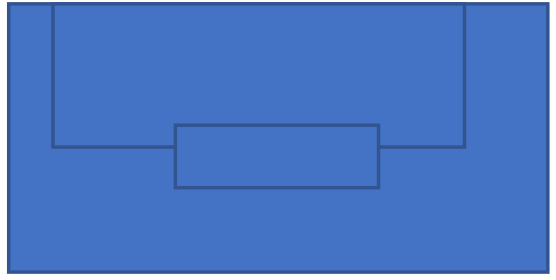

Fig. 1

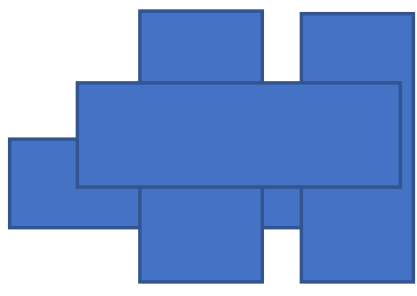

Fig. 2

Fig. 1 exemplifies a traditional, chronological and reliable narrative, where the scope of the frame grows larger as the story progresses, and the reader slowly proceeds towards the bigger picture. In Fig. 2, the overall disruptive composition of the frames is representative of unreliability. The surface of the frames juxtaposed one upon the other represent the confluential creation, the two dimensions as representative of the imaginative process consisting of the interplay of memory and speech act (Iser 12). To put it into a mathematical equation:

$$
\mathrm{I}(\mathrm{c})=\mathrm{m} \times \mathrm{S}(\mathrm{a})
$$

Where $I(c)$ is the confluential content of the creative process, or imagination, $m$ is memory and $S$ represents the speech act. The multiplication of the two dimensions creates the surface/content of the frame.

Unreliability can be manifested within the frame but even more so, it can manifest when the individual $I(c)$ units interact according to their own content with respect to each other. Figure 2 hence displays the latter case. The scattered connections form an absence in the middle. This results in the fact that the reader will always end up with a missing piece that they will somehow have to fill in themselves. Welty's autobiography falls under the scheme of Fig. 1, Robbins' autobiography inclines much more towards Fig. 2.

The common grounds these two possible proposed narrative framings share is that they both relate to memory, although in varying standpoints. In Fig. 1, to achieve the bigger picture, the reader (of an autobiography) always needs to recall the smaller frame(s). In Fig. 2, memory plays just a slightly differently nuanced role for the reader compared to the author.

Although memory serves as the basic source of autobiography as well as of fiction, writing about one's own life is subject to higher dependency on memory, whereas fiction gives more space to imaginative play. From the reader's perspective, this is applicable as well. There is a greater tendency to trust autobiographical writing. However, as mentioned above, literary autobiographies are precisely the imaginative spaces where the reader should be alert and on guard for instances of unreliability. How is it manifested in the cases studied? 


\section{Trauma, Narrative, Responsibility}

Within the category of autobiography, the idiosyncratic author/narrator/protagonist unity is distributed in a way that the author decides on the sizing of the frame, the narrator draws it, and the main character is inside it. This is also true for fiction. However, the burden of blending in all these roles into one person only occurs within the process of autobiographical writing. These specific narratives are a result of this person's living, perception, their writerly voice, and most importantly, their memory.

The two schemes proposed above are by no means binary, they serve more as two limiting poles of a spectrum. Moreover, one can complete the other, so hierarchy can be implied. For example, the individual frames of Fig. 2 can be composed of frames that are the same as those seen in Fig 1. Such a specification fits Robbins' structuring of Tibetan Peach Pie. Its individual chapters are not connected in any straightforward manner, they function rather as separate short stories that give the reader insight into individual, relatively chronological episodes of his life. Inside these, there are haphazard metacommentaries (Robbins' referring to himself as "Tommy Rotten") or symbolically important objects or personas, i.e. motifs (vine-ripe tomatoes, or Johnny Weissmueller as Tarzan) that link them together. These are instances which exemplify his creative voice, since in his fiction, Robbins unfolds the story thanks to the interaction of curious and unexpected allegories, myths and symbols. He whimsically hands out slices of the metaphorical Tibetan peach pie of his life experiences for the reader, making sure not to overfeed them.

Robbins cleverly evades the definition of autobiography while still keeping its boundaries - he deflates any notions of writing for the purposes of the ego: "Autobiography is fueled by ego and I could make a long list of persons whose belly buttons I'd rather be contemplating than my own" (Robbins xv). He withdraws from talking about himself even when he talks about himself.

How can one speak of (un)reliability then? A daring position is to be postulated: the reason why literary autobiographical writing is (un)reliable is that the authors/narrators/main characters use the language of fiction to describe their own lives. Considering other genres that do this, such as historical fiction or biography, they too display degrees of unreliability. However, literary autobiographies (selfwritten accounts of writers' lives) provide a specific angle to the unreliable point of view. In historical fiction, autobiographical novels and biographies, the protagonist/narrator/author unity does not apply. In addition, these are the go-to works where to find first-hand insight on creative writing.

Literary autobiographies are the emblematic spaces where authors give us a sneak peek into how to make lies believable by constructing un-truths. As mentioned above, this is a concept of creative writing, from which we can draw conclusions on how to avoid deception (in fiction). Any sophisticated un-truth can therefore become enjoyable, as well as help us with an understanding of deceptive human nature. Some might argue that other types of life-writing fall under the same conditions. In spite of the non-contestable presence of unreliability in these cases, literary autobiographies (reflections of professional writers on their own journey through writerhood) provide a unique perspective about creation of believability, thanks to the focalization of the creative process of this very believability. 
Literary autobiographies are the only place where the writerly voice comments and mirrors itself openly. They are the only place where the unity of author - narrator - protagonist takes place on a backdrop of their own mind as a creative process of self in a textual form. As Robbins romantically asserts: "That's the value of artists, isn't it? Even when they aren't aware of it, they're dreaming our dreams for us” (Robbins 214).

The two authors chosen for the purposes of this study have matured with their fiction, and both of the authors' witticisms can attest that, they are (not too) recent enough to be dealt with enough immediacy as well as generational distance. This is necessary for self-reflection. Both autobiographies also announce the precise intention for which they were written.

The tone in which Welty describes experiencing her writing process is extremely solemn, thoughtful and explicitly insightful. She puts elements of her own life into fiction this way, such as, for example, when she talks about embedding the Southern custom of bottle trees into her story: "I know that the actual bottle tree, from the time of my actual sight of it, was the origin of my story. I know equally well that the bottle tree appearing in the story is a projection from my imagination” (Welty, One Writer's Beginnings 85). This is Plato's allegory of the cave transposed into the head of a writer. To connect it to the one-of-a-kind perspective described above, the protagonist sits in awe at what the narrator holds up against the light which the author shines from behind. The unreliability thus comes from the fact that they are all the same person.

To illustrate an added level to this allegory, Tom Robbins has a pre-written letter with a shaggy dog tale about the Tibetan peach pie (Tibetan Peach Pie Shaggy Dog Story) - which is part of the title of the book - which he confesses to be a retelling of "the pièce de resistance (the Holy Grail, as it were) in an old shaggy dog story, author unknown, ... a sort of parable about the wisdom of always aiming for the stars, and the greater wisdom of cheerfully accepting failure if you only reach the moon" (Robbins xvi). It is not included in the autobiography, but he sends it to everyone who asks for one via personal correspondence. The tale presents us a life-story of a man who gives up all other things in life except food and spends his life tasting each and every type of dish he can find around the world. The Tibetan peach pie is his holy grail, the last of meals he has not sampled. When he climbs a mountain to get to the only monastery in the world where they serve it, he encounters deception - the monks only have apple pie (Robbins personal correspondence). A whole new layer of unreliability unfolds. This layer reveals itself only when the reader decides to contact Robbins via the address he provides in his autobiography (in his Tibetan peach pie). It is a pseudo-explanatory metanarrative, drawing attention and commenting indirectly on the exact way un-truth supports the unreliability. Robbins teases the reader, putting a strange cherry on top of the pie of his life story by sending this tale to his readers.

Included in the letter with the shaggy dog tale was a promise. I asked if Robbins could answer 6 questions that would help me with the research and, as a greeting I wished him to live as long as Kudra and Alobar, his two main protagonists in Jitterbug Perfume, that is at least 700 years. He promised to answer the questions on his $700^{\text {th }}$ birthday. This blatant un-truth is made believable because it voices his 
Trauma, Narrative, Responsibility

signature fictional style, based on Tibetan crazy wisdom (Reising and Robbins 469). It sets Robbins apart from other writers and does what the unreliable narrator is supposed to do: dodge any direct answers which he could give to the reader, keeping them hooked. "Like downhill skiing ..., it's a tricky combination of complete abandon and strict control" (Happe and Robbins 99). The paradoxical nature is precisely one of the explanatory elements behind deceptive real-life narratives. He continues to assert this by highlighting: "I must contend that the writing of imaginative fiction is such a mysterious enterprise that very little can be said about it that isn't misleading." (Happe and Robbins 101) The same goes for his own life-narrative.

In his 2009 interview with François Happe, when asked about the ideological intentions of his writings, he gives an ambiguous answer, at first commenting on traits of imaginative fiction contesting "power and the strife, suffering, corruption and injustice that power almost always spawns" (Happe and Robbins 95). In spite of this attitude, he then goes on to claim "that fiction has no duty or obligation whatsoever except never to be boring - and even that is usually subjective" (idem). Contradictions are the sap of his fiction, and this imaginative mechanism constitutes a suitable frame of reference to unreliability. It encompasses how he approaches un-truth, focusing primarily on the connection between (seemingly) antagonist principles. This openness manifests his will to give power to the reader on their journey of deciphering his narratives.

To contrast, Welty's fiction and autobiography is bound in different frames. She asserts: "The frame only raises the question of the vision" (Welty, One Writer's Beginnings 89). Her relation to framing narrative in order to make it grow in the reader's mind could be described as almost tactile - she was an ardent photographer. In her own words:

It had more than information and accuracy to teach me. I learned in the doing how ready I had to be. Life doesn't hold still. A good snapshot stopped a moment from running away. Photography taught me that to be able to capture transience, by being ready to click the shutter at the crucial moment, was the greatest need I had ... . And I felt the need to hold transient life in words - there's so much more of life that only words can convey. (One Writer's Beginnings 84)

This desire to capture reality in its completeness, Welty's prepared acute awareness, that is the struggling narrator that Booth describes in his definition. The struggling author in a battle to deal with the truth here is represented by the constant presence of the eye of the story in a moment of confluence. Holding up a frame to reality enabled Welty to put down abstract frames in the form of words which are then transformed into worlds through the reader's eye.

Welty's direct approach is in strong contrast with Robbins' playfulness. In his ever-interdimensional take on his perception of reality in Tibetan Peach Pie, Robbins alludes to memory in a quite special way:

When we fall asleep, our mind is relieved of duty, it goes on recess, takes a play period, starts looking around for recreation. In that playful mode it snatches up images, figures, and locales from our memory vault and rearranges them, often randomly, usually out of context, for its own amusement and stimulation, trying 
different incongruous combinations just to observe the results. Your memory bank is your sleeping mind's toy box. (Robbins 108)

This observation works when we look at both Welty's and Robbins' autobiographical writings, the metaphor of the toy box providing a three-dimensional take on the frame explanation. Imagination takes on a palpable shape. Not only are ideas, situations, people and objects situated within these confined spaces, they may be taken out to be worked with or thrown away into selective oblivion.

While for Robbins, "imagination ha[d] been [his] wild card, [his] skeleton key, [his] servant, [his] master, [his] bat cave, [his] home entertainment center, [his] floatation device, [his] syrup of wahoo" (Robbins 362), Welty plays with memory through the mechanism of confluence. "[T]he greatest confluence of all is that which makes up the human memory-the individual human memory" (Welty, One Writer's Beginnings 104). The unreliability in her writing is, just as in Robbins' recollections of his life, a certain mistrust in memory, since she admits: "[T]ime is also subject to confluence. The memory is a living thing-it too is in transit. But during this moment, all that is remembered joins, and lives-the old and the young, the past and the present, the living and the dead" (Welty, One Writer's Beginnings 104). Although her (autobiographical) writing has a more solemn tone that that of Robbins, she, too, has to deal with the paradox and contradictions of writing imaginative fiction with respect to memory and does so in a rather parallel way to Robbins, accepting the beauty of dissonance.

In summary, Welty and Robbins display cases of unreliability as narrators in their autobiographical writings that enable the reader to decipher the subtle boundaries of what makes the difference between an un-truth and a lie. Narratives function as delineators of referential frames which bind the roles of the author, the narrator and the character. On the one hand, un-truths are the mechanisms that enable the narrative to work, they are working paradoxes. On the other hand, using lies displays a desire to hide truth that their originator wishes to leave hidden, they are paradoxes acting as functional aspects of reality. Simply put, hiding truth in (life) narrative is in direct opposition to hiding truth in real life.

Welty and Robbins both reject the latter dishonesty, they expose the paradoxical nature of lies, making them un-truths, and use various writerly methods to approach them. They manifest seeking truth, while using the means of un-truth. The clearest answers to as to how they do so are to be found in their autobiographies. From there, they may be applied to both the real-life reader and real-world interaction, as well as reflections to help decipher their imaginative worlds. Willful exposure of their own unreliable narrators (a.k.a. themselves) serves to highlight the main principle of writing fiction: calculating the possibilities of perception and the imaginative brought to believable life through words. 


\section{Works Cited:}

Booth, Wayne. The Rhetoric of Fiction. The University of Chicago Press, 1983.

Croci, Giacomo. "A Plea for Spatiality in Thinking Memory. Non-linear Time and Sigmund Freud's Taste for Topography." The Place of Memory and the Memory of Place, edited by Olena Lytovka, pp. 13-31. IRF Press, 2016.

Doležel, Lubomír. Heterocosmica. Karolinum, 2003.

Happe, François and Tom Robbins. “An Interview with Tom Robbins.” Revue française d'études américaines, n. 121, pp. 95-101. Editions Belin, 2009. www.jstor.org/stable/20875903. Accessed August 18th, 2019.

Iser, Wolfgang. “The Reality of Fiction: A Functionalist Approach to Literature.” New Literary History, vol. 7, n. 1, pp. 7-38. The Johns Hopkins University Press, 1975. www.jstor.org/stable/468276. Accessed August 18th, 2019.

Lejeune, Philippe. Le Pacte Autobiographique. Seuil, 1997.

McHaney, Pearl. Eudora Welty as Photographer. University Press of Mississippi, 2009.

"Post-truth.” Oxford Dictionaries. en.oxforddictionaries.com/definition/post-truth. Accessed 20 December 2018.

Reising, Russel and Tom Robbins. “An Interview with Tom Robbins.” Contemporary Literature, vol. 42, no. 3, pp. 463-484. University of Wisconsin Press, 2001. www.jstor.org/stable/i251784. Accessed August 18th, 2019.

Robbins, Alexa. "Tibetan Peach Pie Shaggy Dog Story.” 2014. tibetanpeach.blogspot.com/. Accessed August 18 ${ }^{\text {th }}, 2019$.

Robbins, Tom. Tibetan Peach Pie: A True Account of an Imaginative Life. Ecco Books, 2015.

Schmidt, Silke. "Life Writing Theory: Constructing Life, Claiming Authenticity." (Re-)Framing the Arab/Muslim. Transcript Verlag, 47-136, 2014. www.transcript-verlag.de/en/author/schmidt-silke-320001967/. Accesed August 18 ${ }^{\text {th }}, 2019$.

Welty, Eudora. One Writer's Beginnings. Harvard University Press, 1995.

---. The Eye of the Story. Random House, 1990. 